\title{
PENERAPAN FORUM RHJFOX MENGGUNAKAN METODE PHPBB SEBAGAI MEDIA PEMBELAJARAN PADA PERGURUAN TINGGI RAHARJA
}

\author{
Untung Rahardja ${ }^{1}$ \\ Yessi Frecilia ${ }^{2}$ \\ Noval Jindan ${ }^{3}$ \\ Email : untung@raharja.info,yessi.frecilia@raharja.info,noval@raharja.info \\ Diterima : 17 Desember 2014 / Disetujui : 06 Januari 2015
}

\begin{abstract}
Developed technology rapidly becomes very important and indispensable in the world of education, education requires the media to support the teaching and learning process. The learning method is used to achieve the objectives of learning lecturer. One method that can be used by teachers in the learning process aimed at improvingthe ability of learners which method of discussion. Although many of the container orinstructional media for teaching and learning activities, a container of learning to use the forum is quite effective and very good to support the learning and teaching process, especially on the older students the process of analytical study usingn iLearning device i.e. the iPad on College Raharja. The current obstacle is the difficulty for many of the students use the media discussion of today's modern information technology. To overcome the various problems as described above, can be done by using additional applications in order to support teaching and learning activities using the forum RhjFox. then needed a quick and efficient process to resolve problems that occur above. Current teaching and learning just sitting and listening to the lecturer who was explaining before, unbeknownst to the students understand or are notexplained by the lecturer to even ask sometimes still shy.
\end{abstract}

Keyword : Forum, RhjFox, Learning

\section{ABSTRAK}

Teknologi yang berkembang dengan pesat menjadi sangat penting dan sangat diperlukan dalam dunia pendidikan, dunia pendidikan memerlukan media untuk menunjang proses belajar mengajar. Metode pembelajaran merupakan cara yang digunakan dosen untuk mencapai tujuan pembelajaran. Salah satu metode yang dapat digunakan oleh dosen dalam proses pembelajaran yang bertujuan untuk meningkatkan kemampuan peserta didik yaitu metode diskusi. Meskipun banyak sekali wadah atau media pembelajaran untuk kegiatan proses belajar mengajar, sebuah wadah pembelajaran menggunakan forum cukup efektif dan sangat baik untuk menunjang proses belajar dan mengajar terutama pada anak mahasiswa iLearning yang proses pembelajarannya menggunakan device yaitu iPad pada Perguruan Tinggi Raharja. Yang menjadi kendala saat ini adalah kesulitan para mahasiswa untuk banyak mempergunakan media diskusi yang berteknologi informasi modern saat ini. Untuk mengatasi berbagai masalah seperti yang dijelaskan diatas, dapat dilakukan dengan cara menggunakan aplikasi tambahan untuk menunjang kegiatan belajar mengajar dengan menggunakan forum RhjFox. Maka diperlukan proses yang cepat dan efisien agar dapat menyelesaikan masalah yang terjadi diatas. Saat ini proses belajar mengajar hanya sekedar duduk dan mendengarkan dosen yang sedang menjelaskan didepan, tanpa diketahui mahasiswa tersebut mengerti atau tidak yang dijelaskan oleh dosen tersebut bahkan untuk bertanya kadang masih malu-malu. 


\section{PENDAHULUAN}

Metode pembelajaran merupakan cara yang digunakan dosen untuk mencapai tujuan pembelajaran. Salah satu metode yang dapat digunakan oleh dosen dalam proses pembelajaran yang bertujuan untuk meningkatkan kemampuan peserta didik yaitu metode diskusi. Metode diskusi merupakan salah satu dari beberapa metode pembelajaran yang umum digunakan dalam dunia pendidikan, diskusi merupakan komunikasi seseorang berbicara satu dengan yang lain, saling berbagi gagasan dan pendapat. Namun setiap metode pembelajaran yang diberikan pastinya ada manfaat atau kelemahannya, sehingga para dosen harus memahami berbagai metode pembelajaran agar dosen dapat memilih dan menggunakan metode yang tepat sesuai dengan materi dan tujuan pembelajarannya. Metode pembelajaran yang digunakan diharapkan mampu meningkatkan kemampuan peserta didik dalam proses berpikir dan mengungkapkan pendapat.

Teknologi yang berkembang dengan pesat dan menjadi kebutuhan yang sangat penting membuat dunia pendidikan memerlukan media untuk proses belajar mengajar, yang berdampak pada semua aspek yang berhubungan dengan informasi salah satu perkembangan teknologi adalah RhjFox, maka dari itu untuk mempercanggih suatu proses pembelajaran dengan adanya forum sangat membantu dalam menggunakan metode iLearning[10]. Dimana metode ini mengajak mahasiswa bukan hanya belajar, tapi juga bekerja, bermain dan berdoa. Dalam metode iLearning tersebut terdapat 9 (sembilan) FIR dan salah satunya adalah RhjFox. Menurut Siti Fatimah (2014) RhjFox adalah Forum yang disediakan oleh Perguruan Tinggi Raharja sebagai tempat kegiatan atau hobi. Menurut Yessi Frecilia (2014) : RhjFox merupakan wadah pembelajaran yang dikemas sebagai wawasan aktifitas/kegiatan yang menjadi pokok berbagi informasi dalam bentuk forum.

Metode iLearning[9] dimana RhjFox sebagai media utamanya, namun terintegrasi juga dengan 9 (sembilan) FIR IT lainnya. Dikarenakan untuk mendaftar RhjFox, dibutuhkan pendaftaran (register) menggunakan email Rinfo. Rinfo (Email Rahaja.Info) adalah layanan komunikasi email yang disediakan oleh Perguruan Tinggi Raharja untuk semua Pribadi Raharja, alat komunikasi utama dan paling vital untuk para Pribadi Raharja[11].

Meskipun banyak sekali wadah atau media pembelajaran untuk kegiatan proses belajar mengajar, sebuah wadah pembelajaran menggunakan forum cukup efektif dan sangat baik untuk menunjang proses belajar dan mengajar terutama pada mahasiswa iLearning yang proses pembelajarannya menggunakan device yaitu iPad. Dengan forum Pribadi Raharja bisa saling bertukar pikiran dan saling berdiskusi.

RhjFox merupakan sebuah forum aplikasi CMS phpBB. PhpBB merupakan paket forum internet yang ditulis dengan bahasa pemrograman PHP. Nama "phpBB" merupakan singkatan dari php Bulletin Board dan tersedia dalam GNU (General Public Licence) sehingga didistribusikan sebagai freeware. Perkembangan forum ini tidak terlepas dari pengaruh perkembangan zaman. Kemajuan teknologi bahkan menuntut forum dikemas secara lebih efisien dan mudah. dibawah ini terdapat logo dari phpBB. 


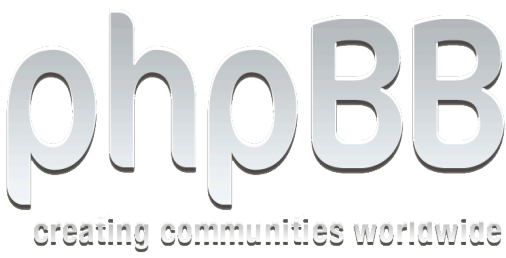

Gambar 1. Logo PhpBB

Pada gambar 1. Merupakan logo dari phpBB yang merupakan CMS dari sebuah forum RhjFox.

Proses belajar mengajar adalah inti aktivitas dalam pendidikan. Proses ini merupakan interaksi yang terjadi antara dosen dan mahasiswa serta dipengaruhi oleh hubungan yang ada dalam proses tersebut. Ini menyebabkan metode belajar mahasiswa juga dipengaruhi oleh metode pengajaran dari doa. Seiring dengan pesatnya perkembangan di dunia telekomunikasi yang ditandai dengan era digital, khususnya di bidang Teknologi Informasi dan Komunikasi (TIK), tentunya proses belajar mengajar juga menuntut adanya penyesuaian atau linearitas institusi pendidikan dalam penggunaan metode proses belajar mengajar. Adanya realita tersebut, Perguruan Tinggi Raharja yang menerapkan konsep IT dalam proses belajar mengajar jelas memerlukan sarana dan prasarana TIK yang up to date untuk menunjang kegiatan Tri Dharma, sehingga dapat menjawab tantangan-tantangan yang ada, khususnya untuk peningkatan kualitas proses belajar mengajar. Salah satu sarana untuk menunjang proses belajar mengajar yaitu dengan konsep iLearning. iLearning memanfaatkan teknologi internet sebagai sarana penyajian dan distribusi informasi. Karena berbasis teknologi internet sehingga media pembelajaran iLearning dapat diakses dari manapun selama tersedia akses ke internet.

Menurut Muhammad Yusuf website tersebut merupakan website forum diskusi online yang memberikan fasilitas kegiatan belajar dikelola tanpa adanya tatap muka langsung di antara pihak-pihak yang terlibat (administrator, moderator, mahasiswa). Kehadiran pihak-pihak yang terlibat diwakili oleh e-mail, chatting, atau melalui video conference. Forum diskusi yang dibuat dalam penelitian ini menggunakan sebuah paket aplikasi Content Management System (CMS) yaitu Ip.Board. Sementara itu implementasi dari forum diskusi ini dapat digunakan untuk memberikan solusi terhadap permasalahan yang sedang berjalan dalam proses belajar mengajar yang selama ini terbatas pada masalah waktu dan tempat.

\section{PERMASALAHAN}

Dalam pembelajaran tidak ada aturan yang melarang teknologi sebagian dari sarana forum selama masih bersifat positif bagi penggunanya. Seharusnya yang harus diketahui bahwa salah satu prinsip dalam, dimana diskusi harus disesuaikan dengan kondisi zaman yang dimana diskusi itu dapat dilaksanakan. Karena itu sangat tepat kiranya, apabila di era informasi dan komunikasi ini kita memanfaatkan teknologi sebagai media diskusi, yaitu suatu media yang dapat membuat mereka menerima. Diskusi merupakan metode teknologi dan suatu media yang dapat mendekatkan bagi mereka yang kurangnya akan sharing dalam suatu komunikasi atau tidak adanya keberanian untuk mengungkapkan.

Ternyata penggunaan teknologi sebagai suatu media forum mendapat respons yang positif dari mahasiswa. Diskusi yang baik harus direncanakan dan kunci ke berhasilannya terletak pada isu atau masalah yang didiskusikan. Pemilihan topik diskusi dapat mempengaruhi keberhasilan diskusi sehingga topik harus dipilih dengan baik. Di tegaskan pula bahwa secara umum ada beberapa standar penentuan topik masalah 
yang dapat menjadi masalah yang baik dalam penerapan metode diskusi. Berikut ini standar-standar yang dimaksud :

a. Semua atau sebagian besar kelompok anggota sangat tertarik terhadap masalah yang didiskusikan.

b. Masalah yang dikaji sudah dikenal baik oleh sebagian besar anggota kelompok.

c. Masalah bersifat jelas, dan dimengerti oleh semua anggota kelompok.

Hal ini terbukti efektifitas kecanggihan teknologi yang kini telah masuk ke setiap kecil dalam perkembangan teknologi yang sudah ada, media mutakhir ini turut melebarkan sayap media diskusi pembelajaran yang selama ini terbatas oleh ruang dan waktu. Dari uraian diatas dapat disimpulkan bahwa media diskusi pembelajaran dengan menggunakan RhjFox sebagai medianya ternyata memiliki kekurangan yang terjadi pada saat diskusi, yaitu minimnya jumlah para member yang belum mengetahui adanya suatu informasi dalam media diskusi pembelajaran. Dari sini diskusi pembelajaran di dalam kelas biasanya akan membuat mahasiswa menjadi tidak semangat, dengan membuat suatu media diskusi pembelajaran iLearning yang dapat di akses secara online, hal ini pasti akan mempermudahkan mahasiswa menjadi lebih nyaman pada saat akan melakukan diskusi bersama dosen dan mahasiswa lainnya. Ini pula akan membuat mahasiswa menjadi termotivasi untuk mengetahui sekaligus mendalami dalam melakukan diskusi diluar jam pelajaran.

Metode diskusi sebagai suatu kegiatan belajar mengajar yang membincangkan suatu topik atau masalah yang dilakukan oleh dua orang atau lebih (dapat dosen dan mahasiswa lainnya). Dimana orang yang berbincang memiliki perhatian yang sama terhadap topik atau masalah yang menjadi pokok pembicaraan, sehingga mendapatkan berbagai alternatif jawaban terhadap topik yang didiskusikan. Dalam diskusi, setiap mahasiswa turut berpartisipasi secara aktif dan turut aktif pula dalam memecahkan masalah. Semakin banyak mahasiswa yang terlibat, semakin banyak pula yang mereka pelajari. Dengan melaksanakan metode diskusi maka suasana kelas akan menjadi semakin hidup, setiap anak diharapkan menjadi berpartisipasi secara aktif. Dalam diskusi, peranan dosen sebagai pusat pemberi informasi dan pemberi ketegasan. Sehingga dosen hanya sebagai pengatur dan penunjuk jalannya pelaksanaan diskusi. Sedangkan pemecahan masalah diserahkan kepada semua mahasiswa. Sebagai pengatur jalannya diskusi, dosen harus bisa mengendalikan mahasiswa agar tidak memotong pembicaraan mahasiswa lain dan tidak ramai sendiri ketika proses diskusi berlangsung, sebagai pendorong mahasiswa yang lain agar ikut berpartisipasi mengungkapkan pendapat dan menurunkan ketegangan di dalam kelas ketika dalam diskusi terjadi perbedaan argumentasi. Selain itu dosen harus menjelaskan kembali apa yang menjadi pokok permasalahan apabila ada gejala-gejala pembahasan akan menyimpang pada persoalan semula dan yang paling penting, dosen menyimpulkan semua yang telah dikemukakan oleh mahasiswa, di mana titik pertemuanya dan titik perbedaannya di jelasakan kembali kepada mahasiswa tersebut.

Yang menjadi kendala saat ini adalah kesulitan para mahasiswa untuk banyak mempergunakan media diskusi yang berteknologi informasi modern saat ini. Lagi pula banyaknya member mengakses, banyaknya data yang difilter dan kurangnya member yang akan masuk ke RhjFox. Akhirnya akan berdampak dan akan mempengaruhi proses implementasi tersebut, untuk mengatasi masalah tersebut suatu media diskusi pembelajaran online yang menghadirkan sebuah RhjFox akan 
mempermudah mahasiswa pada saat akan berdiskusi. RhjFox ini merupakan sebuah media diskusi yang bisa diakses dengan cara online. Kronolognya yaitu :

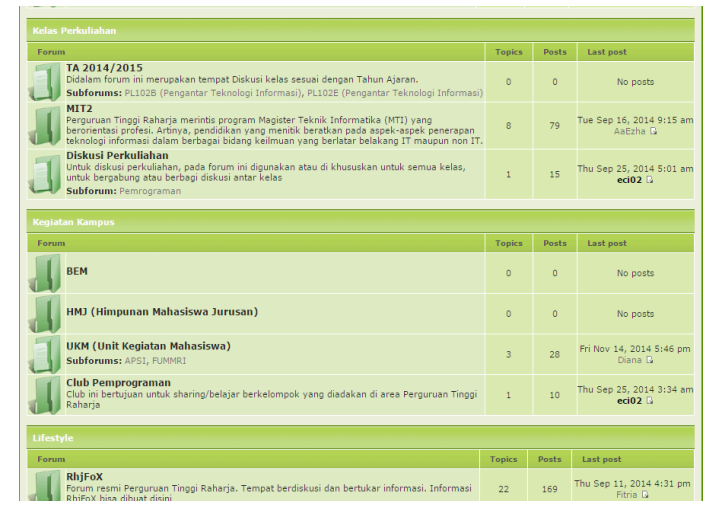

\section{Gambar 2. RhjFox media diskusi yang dirancang untuk mempermudah pembelajaran.}

Dari gambar diatas, terdapat kategori kelas diskusi mahasiswa bisa mengakses RhjFox untuk mempermudah media dikusi pembelajaran dan tidak akan lagi malu untuk mengeluarkan pendapat mengenai pembahasan yang akan disampaikan. Apa yang terjadi bila sebuah pembelajaran dilakukan secara modern. Dikatakan modern, karena dikemas secara ringkas, interaktif dan menjadi sebuah metode pembelajaran secara iLearning.

RhjFox yang merupakan media diskusi pembelajaran digital yang menggunakan diskusi modern yang berisikan kumpulan pertanyaan \& pemecahan masalah. Dilihat dari fitur yang terdapat di RhjFox ini terdapat beberapa kategori tentang pembelajaran yang sangat bermanfaat. Tidak hanya sebagai media pembelajaran, Dalam RhjFox ini juga terdapat sharing informasi yang berisi kategori lifestyle dengan seputar informasi. Dari media dikusi pembelajaran, karya yang diluncurkan oleh RhjFox ini merupakan hal baru yang sangat efektif.
Dari pembahasan diatas, dapat dirumuskan satu permasalahan yaitu sebagai berikut :

1. Apakah RhjFox dapat membantu mahasiswa agar lebih mengeluarkan pendapatnya dengan metode media diskusi sebagai pembelajarannya?

\section{LITERATURE REVIEW}

Banyak penelitian yang sebelumnya dilakukan berkenaan dengan Literature Review mengenai konsep antara diskusi dengan teknologi. Dalam upaya mengembangkan RhjFox ini perlu dilakukan studi pustaka sebagai salah satu dari penerapan metode penelitian yang akan dilakukan. Diantaranya adalah mengidentifikasikan kesenjangan dan mengidentifikasikan metode yang pernah di lakukan, meneruskan penelitian sebelumnya, serta untuk mengetahui orang lain yang spesialisasi dan area penelitiannya sama di bidang ini. Beberapa Literature Review tersebut adalah sebagai berikut :

1. Penelitian Jurnal Ilmiah yang dilakukan oleh Muhamad Yusup, Sri Rahayu, dan Desi Ermita dari Perguruan Tinggi Raharja pada tahun 2012 di Perguruan Tinggi Raharja yang berjudul "Desain Forum Diskusi Mahasiswa Sebagai Media Pembelajaran iLearning Pada Perguruan Tinggi”. Menjelaskan bahwa proses belajar mengajar adalah inti aktivitas dalam pendidikan. Proses ini merupakan interaksi yang terjadi antara dosen dan mahasiswa serta dipengaruhi oleh hubungan yang ada dalam proses tersebut. Seiring dengan pesatnya perkembangan di dunia telekomunikasi yang ditandai dengan era digital, khususnya di bidang Teknologi Informasi dan 
Komunikasi (TIK). Perguruan Tinggi Raharja yang menerapkan konsep IT dalam proses belajar mengajar jelas memerlukan sarana dan prasarana TIK yang up to date untuk menunjang kegiatan serta peningkatan kualitas proses belajar mengajar. Salah satu sarana untuk menunjang proses belajar mengajar yaitu dengan konsep iLearning.[1]

2. Penelitian ini dilakukan oleh Muhammad Amiral pada tahun 2009 yang berjudul "Analisis Dan Implementasi Forum Diskusi Menggunakan PHPBB 3.04 di PDSI ITI". Penelitian ini membahas tentang meningkatnya keinginan masyarakat khususnya civitas akademika ITI dalam berkomunitas secara online, maka dikembangkan secara langsung Aplikasi Forum Berbasis Web bagi civitas akademika ITI. Dengan adanya Forum Berbasis Web dapat menjadi wadah untuk menjembatani kesamaan hoby, aktivitas, ataupun keinginan yang sama antar civitas akademika ITI dalam dunia maya.[2]

3. Research yang telah dilakukan oleh Isnaini dan Bagus Qomarudin [2009] penelitian ini berjudul "Perancangan dan pembuatan forum diskusi siswa MAN 2 Bojonegoro berbasis WEB'. Menjelaskan sebuah forum yang dijadikan media atau alat untuk saling berinteraksi dan berdiskusi antar pelajar dengan menggunakan alat bantu yaitu internet untuk memudahkan pelajar mengaksesnya kapanpun dan dimanapun, mempercepat untuk mendapat informasi. Dalam sisi pengembangan lebih mudah, karena banyaknya milis-milis dan developer yang siap membantu dalam pengembangan, memberikan kemudahan untuk saling berinteraksi antar siswa maupun dengan dosen. Adapun dampak yang akan didapat yaitu terlalu mengandalkan forum untuk berdiskusi dari pada mengadakan pertemuan, pemrograman yang digunakan adalah PHP, php adalah bahasa open source yang dapat digunakan di berbagai mesin (Linux, Unix, Macintosh, Windows) dan dapat dijalankan secara runtime melalui console serta juga dapat menjalankan perintah-perintah system, data yang terlalu banyak akan memberikan dampak lambatnya akses yang didapat, untuk file seperti audio dan video masih belum efektif karena database yang belum mendukung besarnya data, dibutuhkan extra security karena coding php sudah familiar dan banyak dipelajari, dan tidak mengenal package.[3]

4. Penelitian yang dilakukan oleh Untung Rahardja, Ary Budi Warsito, dan Dini Nurul Suvianti dari Perguruan Tinggi Raharja pada tahun 2012 dengan judul "Penerapan Aplikasi iDINI Sebagai Media Penyimpanan Materi Perkuliahan iLearning Pada Perguruan Tinggi" menjelaskan bahwa perlu adanya perubahan metode pembelajaran yang dapat menciptakan suasana kelas serta membuat mahasiswa lebih bersemangat. Maka diperlukannya proses yang cepat dan efisien dalam mengakses seluruh data yang banyak terutama dalam media penyimpanan. Integrated Download iBooks in iPad disingkat menjadi iDINI, merupakan media pendukung pembelajaran iLearning yang berupa sebuah aplikasi. Penggunaan aplikasi ini sebagai media penyimpanan bahan ajar 
materi perkuliahan yang dapat meningkatkan aktivitas mahasiswa dalam pembelajaran iLearning. [4]

5. Penelitian yang dilakukan oleh Maimunah, Kristiana dan Hendra dari Perguruan Tinggi Raharja tahun 2010 yang berjudul "Perancangan Aplikasi Forum Diskusi Pada Media E-Learning Berbasis Web". Penelitian tersebut menjelaskan bahwa pentingnya forum diskusi dalam proses belajar-mengajar. Oleh, karena itu dibuatlah aplikasi forum diskusi untuk pembelajaran " $e$ learning" yang dapat mengkomunikasikan peserta didik dengan pengajar dimana aplikasi ini dapat menghemat waktu belajarmengajar, mengurangi biaya perjalanan, menghemat biaya pendidikan, dan mampu menjangkau wilayah geografis yang lebih luas serta melatih pelajar agar lebih mandiri dalam mendapatkan ilmu pengetahuan.[5]

6. Penelitian ini dilakukan oleh Untung Rahardja, Muhamad Yusup dan Eva Rosyifa dari Perguruan Tinggi Raharaja tahun 2012 yang berjudul "Perancangan Aplikasi iLearning Majalah Online Dengan Menggunakan iOS Programming Pada Perguruan Tinggi". Penelitian ini membahas sifat publikasi penyampaian informasi bersifat penting karena dapat membantu dan melakukan pencarian akan informasi yang sebelumnya tidak diketahui. Serta media publikasi masih berkaitan satu sama lain sehingga kebutuhan akan informasi sifatnya masih sangat tinggi dan dari sebagian tempat sifatnya masih sangat rendah dan proses update akan informasi masih bersifat minim. Sehingga diharuskan melakukan perancangan aplikasi iLearning majalah online dengan menggunakan iOS Programming, yang diharapkan bisa di akses melalui iPhone dan iPad yang bisa di download melalui iTunes demi meningkatkan peran media dalam perguruan tinggi supaya jauh lebih baik dan tentunya bermanfaat.[6]

7. Research yang telah dilakukan oleah Tri Atmojo [2010] yang berjudul "Membangun Design Website Elearning Menggunakan Moodle pada STIMIK Raharja". Adalah sebuah system pembelajaran yang dibuat dengan software Course Management System (CMS) yang berbasis internet. Sebagai aplikasi yang open source pasti mempunyai kelebihan dan kekurangan yang dimiliki oleh system ini diantaranya yaitu: Waktu akses yang lambat karena bandwidth yang kecil dan buruknya perancangan materi yang memiliki ukuran file yang besar (akibat adanya unsu audio, video), kurangnya system security karena system yang menggunakan open source mudah untuk dipelajari oleh semua orang. Adapun keunggulan dari system ini yaitu : program $e$ learning dapat dilaksanakan dan diupdate secara cepat, Materi dapat dirancang secara multimedia dan dinamis, desain yang user friendly sehingga mudah dalam penggunaan. Tempat sebagai kelas tidak membutuhkan bentuk fisik lagi, semuanya dapat dibangun dalam aplikasi internet dan menghemat biaya, system ini dapat member efesiensi waktu dan efektifitasi dalam segi biaya dan tenaga. Adapun kekurangan yang ada pada system diantaranya kapasitas untuk data terbatas jika semakin banyak data 
semakin lambat akses penggunaannya, design yang permanen dan tidak dinamis kurang member dampak menarik.[7]

8. Penelitian dilakukan oleh Rano Kurniawan, Henderi, dan Fitria Nursetianingsih. Meneliti tentang pembelajaran menggunakan iPad. Dalam penelitian ini digunakan metode iLearning (Integrated Learning), yaitu pembelajaran online menggunakan iPad. Dimana iLearning ini berkaitan erat dengan 4B (Belajar, Bekerja, Bermain dan Berdoa). Dengan adanya iPad sebagai penunjang pendukungnya, diharapkan pembelajaran ini akan berjalan dengan efektif dan efisien. Dan perlu diketahui bahwa iLearning merupakan salah satu terobosan baru dalam metode pembelajaran yang telah menggunakan iPad sebagai standarisasinya. Mahasiswa iLearning dengan sarana pendukung iPad dapat menciptakan integritas yang baik untuk metode pembelajaran. Dengan satu sentuhan jari mahasiswa dengan mudah melakukan berbagai aktifitas. iLearning berkaitan dengan 4B (Belajar, Bekerja, Bermain dan Berdoa). Melalui iLearning belajar jadi menyenangkan dan realisasinya menyatu dengan kehidupan seharihari serta ilmu pengetahuan dapat diserap optimal secara efektif dan efisien.[8]

Dari tujuh literature review yang ada, telah banyak penelitian mengenai metode pembelajaran menggunakan media forum atau yang lainnya. Itulah alasan mengapa penulisan ini membahas hal tersebut. Agar nanti bisa dijadikan acuan sebagai referensi oleh dosen maupun mahasiswa.

\section{PEMECAHAN MASALAH}

Untuk mengatasi berbagai masalah seperti yang dijelaskan diatas, dapat dilakukan dengan cara menggunakan aplikasi tambahan untuk menunjang kegiatan belajar mengajar dengan menggunakan forum RhjFox, maka diperlukan proses yang cepat dan efisien agar dapat menyelesaikan masalah yang terjadi diatas. Saat ini proses belajar mengajar hanya sekedar duduk dan mendengarkan dosen yang sedang menjelaskan didepan, tanpa diketahui mahasiswa tersebut mengerti atau tidak yang dijelaskan oleh dosen tersebut bahkan untuk bertanya kadang masih malu-malu. Forum RhjFox dapat membantu mahasiswa agar lebih paham dan dapat memotivasi untuk bertanya tanpa ada rasa malu bertanya. Forum RhjFox bukan hanya sekedar media untuk belajar mengajar seperti biasa namun bisa juga digunakan sebagai media mencari informasi. sistem yang berjalan pada saat ini masih menggunakan forum discussion offsite class pada iDu. Pada discussion offsite class yang terdapat di dalam iDu masih mempunyai kekurangan, tidak bisanya menyisipkan file dalam suatu thread atau diskusi dan juga tidak ada beberapa fitur yang ada di berbagai forum yaitu adanya fitur emoticon dan fitur quote. Berbeda dengan forum RhjFox, pada forum RhjFox sudah memiliki beberapa fitur pendukung pada saat memulai diskusi. Fitur ini juga sangat membantu dan menunjang kegiatan pada saat belajar mengajar, dan agar mahasiswa tidak bosan apabila suatu forum diskusi berisi hanya teks saja tidak di sertai dengan gambar. Dengan menggunakan RhjFox, dosen dapat memasukan materi yang akan di share untuk mahasiswa yang nantinya juga untuk di diskusikan kepada mahasiswa tersebut. 
Semua Pribadi Raharja bisa menggunakan Rhjfox. Jika semua Pribadi raharja dapat menggunakan sistem RhjFox ini tentu saja yang akan disampaikan akan lebih santai, dan pasti lebih meningkatkan kepahaman dalam belajar mengajar didalam diskusi tersebut. Tentu saja semua Pribadi Raharja bisa menggunakan RhjFox tersebut, sistem ini mempunyai fasilitas berupa sharing file dan iPad juga bisa diakses untuk kepentingan pada saat menjalankan aktivitasnya pada saat berdiskusi. Dan berikut ini adalah gambaran skema dari antara dosen dan mahasiswa dengan teknologi yang akan digabungkan dan dihubungkan menjadi sebuah metode iLearning pada saat akan berdiskusi, yang akan memudahkan arus perkembangan pada saat akan menyampaikan materi kepada mahasiswa dengan menggunakan teknologi iLearning offsite class discussion RhjFox. Supaya dalam skema yang akan dibuat, nantinya akan dilakukan oleh dosen dengan mahasiswa untuk kegiatannya pada saat berdiskusi.

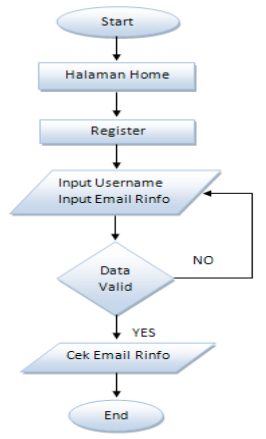

Flowcart 1. Flowchart Register RhjFox

Gambar di atas menjabarkan proses registrasi RhjFox. Langkah pertama adalah mengunjungi halaman home http://rhjfox.com/. Lalu pilih page Register. Kemudian memasukan username dan email Rinfo.

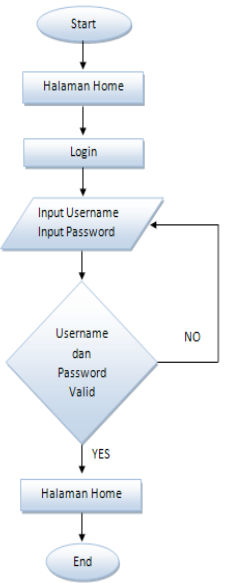
Flowchart 2. Flowchart proses Login
RhjFox

Gambar di atas menjabarkan proses login RhjFox. Dimulai dari mengunjungi halaman http://rhjfox.com. Lalu memasukkan username dan password. Jika username dan password yang dimasukkan valid, maka user berhasil masuk ke halaman home dalam keadaan login.

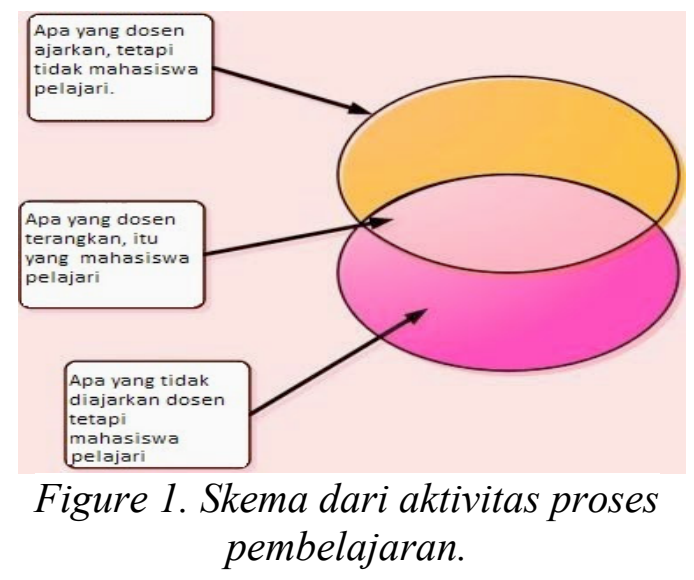

Pada gambar diatas adalah figure dimana lingkaran menunjukkan terdapat dua aktivitas dalam pembelajaran yaitu belajar dan mengajar. Terdapat tiga kemungkinan yang dapat terjadi pada kegiatan pembelajaran. (1) Apa yang dosen ajarkan tidak mahasiswa pelajari. (2) apa yang dosen ajarkan mahasiswa pelajari. (3) apa yang mahasiswa pelajari tidak dosen ajarkan. 


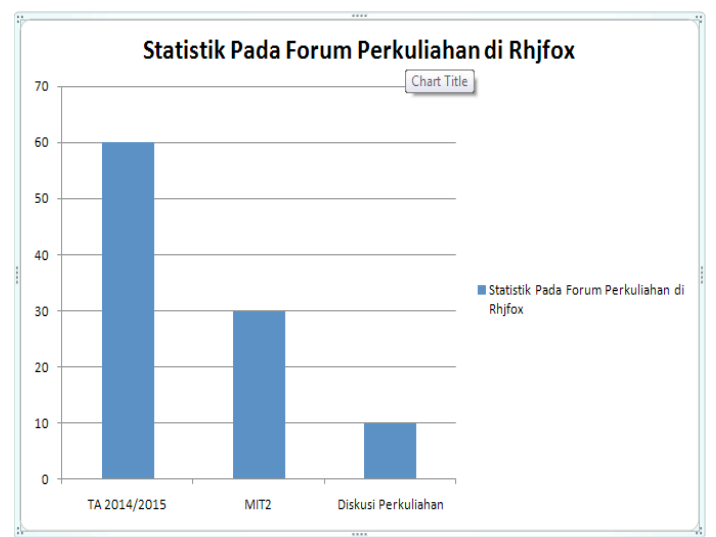

Diagram 1. Statistik pada forum kelas perkuliahan pada forum Rhjfox.

Grafik diatas menunjukan adanya kelas perkuliahan pada forum RhjFox. Ini menunjukan bahwa forum RhjFox memang sudah di terapkan pada kegiatan belajar mengajar pada Perguruan Tinggi Raharja. Pada Forum TA 2014/2015, MIT2 mendapatkan peringkat tinggi pada kelas perkuliahan di forum RhjFox.

Adapun proses input outputnya yang ada di forum RhjFox sebagai berikut :

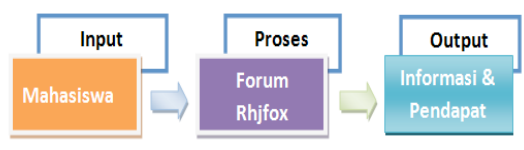

\section{Gambar 4. Suatu kerangka Dalam Forum RhjFox}

Pada gambar 5 tersebut adalah suatu kerangka forum RhjFox yang dilakukan pada saat proses pembelajaran. Disini ada input yang dimana mahasiswa memasuki forum untuk berdiskusi sebagai prosesnya mahasiswa menggunakan forum RhjFox sebagai wadah atau media pembelajarannya, kemudian untuk output atau keluarannya mahasiswa mendapatkan sebuah informasi dan mengasah pendapat dari mahasiswa. kelebihan dari forum RhjFox sangat berbeda dengan forum yang lain. Karena forum ini mempunyai beberapa ciri khas yang menjadi unggulan untuk meningkatkan proses pembelajaran dalam kelas iLearning, dan karena itu ciri khas juga dijadikan sebagai mayoritas utama untuk berkembangnya kemajuan teknologi semakin canggih dan modern. Dengan Rhjfox ini, dosen dan mahasiswa dapat berdiskusi diluar jam pelajaran untuk memaksimalkan sistem pembelajaran iLearning di Perguruan Tinggi Raharja. Sehingga belajar pun lebih efektif, efisien dan menyenangkan sesuai konsep iLearning. Dari 10 (sepuluh) kelebihan, ada 3 (tiga) yang akan ditampilkan, antara lain :

1. RhjFox merupakan sebuah forum dengan menggunakan metode iLearning. Kenapa iLearning, Karena perkembangan dunia IT semakin meningkat, demi mengikuti arus zaman yang canggih dalam metode pembelajaran saat ini.

2. Rhjox menjadi sangat istimewa karena hal-hal yang terdapat didalamnya menyajikan informasi yang berhubungan dengan Perguruan Tinggi Raharja maupun informasi dari pengetahuan luar Perguruan Tinggi Raharja.

3. RhjFox juga menjadi tempat untuk bertukar informasi tentang suatu kesamaan permasalahan, hobbi atau berdiskusi untuk civitas Pribadi Raharja.

Dari 3 (tiga)kelebihan yang dijelaskan dari 10 (sepuluh) kelebihan diatas RhjFox tersebut, RhjFox mempunyai perbedaan dengan forum lain. Karena forum RhjFox ini memang lebih di peruntukan untuk mahasiswa iLearning pada Perguruan Tinggi Raharja.

RhjFox masih mempunyai kekurangan diataranya Ruang lingkup hanya Perguruan Tinggi Raharja, tidak bisa dari luar melainkan hanya untuk mahasiswa Perguruan Tinggi Raharja. Yang bukan 
berasal dari Perguruan Tinggi Raharja hanya bisa melihat saja tidak bisa terlibat didalamnya.

Ada 5 (Lima) kegunaan dari RhjFox, antara lain :

1. Pembelajaran Jarak Jauh

2. Pembelajaran: tanggapan pribadi di forum RhjFox tidak terbatas waktunya. Mahasiswa memiliki kebebasan untuk melanjutkan dialog tentang topik yang mereka paling sukai.

3. Berpikir kritis: Topik forum RhjFox yang efektif, terbuka dan dirancang untuk mendorong Civitas Perguruan Tinggi Raharja. Untuk menanggapi topik forum RhjFox memerlukan pemikiran terorganisir dan sintesis dari konsep yang diperkenalkan.

4. Otonomi Pribadi Raharja: Civitas Pribadi Raharja memiliki fleksibilitas untuk merefleksikan pikiran mereka dan membaca tanggapan.

5. Lebih banyak pertukaran demokratis: Dalam setiap kelas 25-30 Mahasiswa, akan ada kepribadian yang dominan, dan mahasiswa yang mungkin merasa tidak termotivasi untuk berbicara.

\section{IMPLEMENTASI}

Tampilan website forum RhjFox yang memiliki berbagai macam fitur yang dapat digunakan oleh mahasiswa maupun dosen yang terdiri dari:

\section{a. Halaman Utama}

forum tersebut dapat diakses di luar kampus oleh dosen maupun mahasiswa dengan menuju alamat website http://rhjfox.com

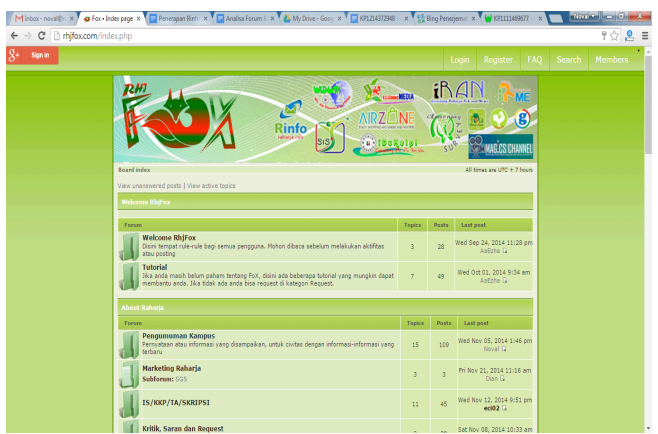

b. Login pada forum RhjFox seperti forum lainnya adanya login untuk masuk ke dalam website forum agar bisa membalas atau memposting suatu artikel.

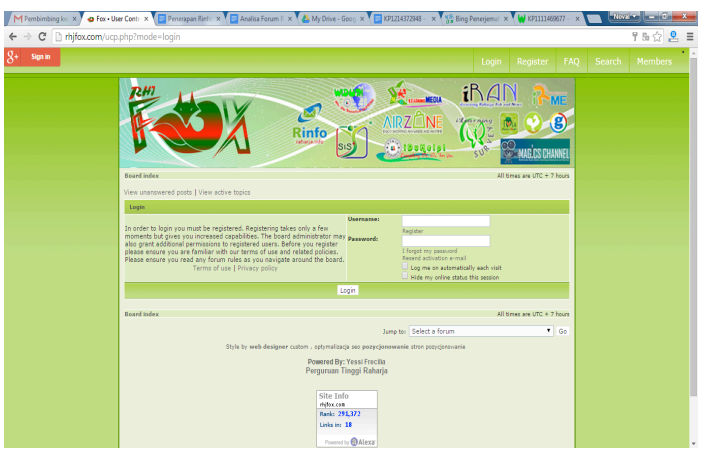

c. Adanya thread atau forum yang dikhususkan untuk anak iLearning yaitu MIT2 jenjang serjana S2. Dan sudah ada aktivitas didalamnya diskusi para mahasiswa MIT2.

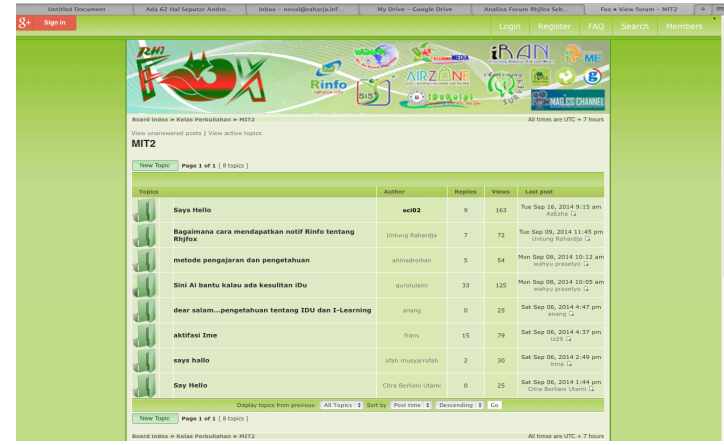

d. Adanya kegiatan belajar mengajar didalam thread RhjFox yaitu dikelas perkuliahan PTI (Pengantar Teknologi Informasi). Ini membuktikan bahwa media 
forum sebagai wadah pembelajaran dinilai sangat efektif sekali.

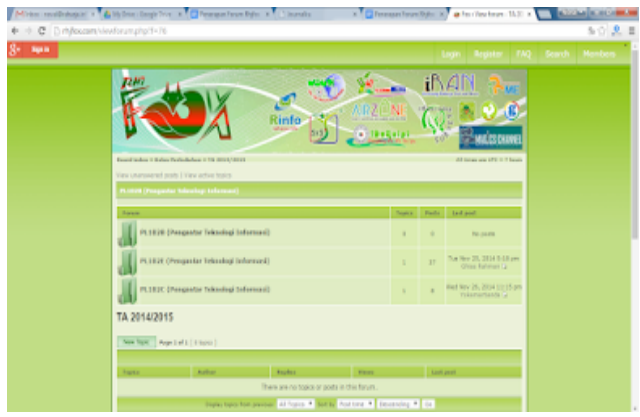

e. Adanya header pada RhjFox yang sudah di link dan juga dapat mengakses ke 10 pillar iLearning (TPi). Ini untuk memudahkan mahasiswa iLearning untuk mengakses TPi dengan cukup mengklik gambar.

\section{Rinfo [i.s)}

\section{KESIMPULAN}

Dengan demikian dapat disimpulkan bahwa RhjFox dapat membantu mahasiswa untuk mengeluarkan pendapat, ini dikarenakan mahasiswa bebas mengeluarkan pendapat didalam forum diskusi perkuliahan tersebut. Seperti yang banyak ditemukan pada proses belajar mengajar dengan metode pembelajaran biasa yang mahasiswa hanya duduk mendengarkan dosen menjelaskan tanpa tahu mahasiswa mengerti atau tidak apa yang di sampaikan oleh dosen. Dengan RhjFox mahasiswa dapat langsung berinteraksi dengan dosen maupun dengan mahasiswa lainnya. RhjFox sebagai media pembelajaran cukup efektif dalam proses belajar mengajar. RhjFox di Perguruan Tinggi Raharja akan dapat mendukung proses pembelajaran yang ada, khusunya metode pembelajaran iLearning yang sudah diterapkan di Perguruan Tinggi Raharja sejak tahun 2009. Dilihat dari segi keamanannya sudah baik, yang nantinya juga integrasi dengan TPi yang hanya bisa diakses menggunakan akun Rinfo. Kemudian, banyak tools di RhjFox yang dapat mendukung proses pembelajaran. Terdapat attachment, yang memudahkan untuk menyisipkan berkas berupa gambar atau dokumen lainnya. Terdapat header yang memudahkan akses ke TPi, sehingga mahasiswa atau dosen lebih mudah untuk mengakses TPi tidak perlu ngetik URL akan tetapi cukup dengan sekali klik sudah bisa mengakses TPi. Terdapat Emoticon yang membantu agar supaya ketika mahasiswa membalas posting atau membuat posting semakin menarik dengan adanya emoticon. Terdapat pangkat setiap member yang dinilai dari banyaknya posting. dan masih banyak lagi tools-tools yang terdapat di RhjFox guna mendukung peroses belajar mengajar yang lebih modern dan lebih baik lagi. Dan juga cara penggunaan RhjFox cukup mudah dan cepat dipahami cara-cara penggunaan RhjFox. Hanya dengan cara register dengan menggunakan email Rinfo mahasiswa atau dosen sudah memiliki akun Rhjfox. Dengan RhjFox segalanya menjadi mudah dan belajar menjadi menyenangkan dan tidak bosan.

\section{DAFTAR PUSTAKA}

1. Yusup,Muhamad. Sri Rahayu, Desi Ermita, (2012) "Desain Forum Diskusi Mahasiswa Sebagai Media Pembelajaran iLearning Pada Perguruan Tinggi". CCIT Journal Vol.5 No.3.

2. ,Muhammad (2009) “Analisis Dan Implementasi Forum Diskusi Menggunakan PHPBB 3.04 di PDSI ITI'. CCIT Journal Vol.1 No.1 
3. Isnaini, Bagus Qomarudin [2009] "Perancangan dan pembuatan forum diskusi siswa MAN 2 Bojonegoro berbasis WEB".

4. Rahardja,Untung, Ary Budi Warsito, Dini Nurul Suvianti (2012) "Penerapan Aplikasi iDINI Sebagai Media Penyimpanan Materi Perkuliahan iLearning Pada Perguruan Tinggi".

5. Maimunah, Kristiana, Hendra (2010) "Perancangan Aplikasi Forum Diskusi Pada Media E-Learning Berbasis Web".

6. Rahardja,Untung, Muhamad Yusup, Eva Rosyifa (2012) "Perancangan Aplikasi iLearning Majalah Online Dengan Menggunakan iOS Programming Pada Perguruan Tinggi". Vol.6 No.1.

7. Atmojo, Tri [2010] "Membangun Design Website Elearning Menggunakan Moodle pada STIMIK Raharja".

8. Rano, Henderi, Fitria Nursetianingsih. (2012, Juni) "Penggunaan iPad Mendukung Pembelajaran pada Mahasiswa iLearning" [Online]. Tersedia di http://www.academia.edu/

9. Henderi, Muhamad Yusup, Yulika Ayu Rantama (2013) "Penggunaan Metode iLearning Untuk Meningkatkan Kualitas Pembelajaran di Perguruan Tinggi”. CCIT Journal Vol.6 No.3.

10. I.D.Dewi, Untung Rahardja, Rahma Rinie (2014) "iLearning Metode Belajar Efektif Untuk Sekolah Tinggi”. CCIT Journal Vol.7 No.3.

11. Rahardja,Untung. Khanna Tiara, Ray Taufik Wijaya (2014) "Penerapan Rinfo Sebagai Media Pendukung Untuk Proses Pembelajaran Pada Perguruan Tinggi Raharja”. CCIT Journal Vol.8 No.1. 